\title{
High Incidence of Complete Ossification of the Superior Transverse Scapular Ligament in Brazilians and its Clinical Implications
}

\author{
Alta Incidencia de Osificación Completa del Ligamento Escapular Transverso Superior en Brasile- \\ ños y sus Implicancias Clínicas
}

"Silva, J. G.; **A Abidu-Figueiredo, M.; ****Fernandes, R. M. P.;

${ }^{* * * * *}$ Aureliano-Rafael, F.; ${ }^{* * * *}$ Sgrott, E. A.; ${ }^{* * *}$ Silva, S. F. \& ${ }^{* * *}$ Babinski, M. A.

SILVA, J. G.; ABIDU-FIGUEIREDO, M.; FERNANDES, R. M. P.; AURELIANO-RAFAEL, F.; SGROTT, E. A.; SILVA, S. F. \& BABINSKI, M. A. High incidence of complete ossification of the superior transverse scapular ligament in Brazilians and its clinical implications. Int. J. Morphol., 25(4):855-859, 2007.

SUMMARY: The aim of this study was to verify the prevalence of the ossified superior transverse scapular ligament (STSL) on dry bones of scapulae. 221 dry bones were analyzed, (111 rights and 110 lefts), proceeding from Rio de Janeiro and of Santa Catarina, Brazil. As exclusion criterion, were not analyzed bones of children or damaged. For the quantitative analysis of the data, the software Graphad Instat was used. Fisher exact test was used considering the $\mathrm{p} \leq 0,05$ as significant. After analysis of the scapulae, 30,76\% (68/ 221 ) presented the ossified STSL ( $\mathrm{p} \leq 0,0001)$ of which, 52,94\% (36/68) were ossified on the right side and 47,05\% $(32 / 68)$ on the left one. The 153 scapulae that did not present the ossified STSL, it was observed in 19,6\%(30/153) of these bones, the superior edge varying in the transverse plan, increasing superior angulation and, modified the width and depth of the scapular incisure. This anatomical curiosity should be kept in mind by clinicians that approaches painful syndrome of the shoulder, as well as, this anatomical curiosity should be kept in mind by students that may manipulate this anatomical area.

KEY WORDS: Gross Anatomy; Variation; Scapula; Superior transverse scapular ligament.

\section{INTRODUCTION}

The suprascapular notch is roofed by the superior transverse scapular ligament (STSL) converting it into foramen in some species (Khan, 2006). In humans, this conversion is a result of the ossification of the STSL (Gardner et al., 1988; Bergman et al., 1988, Williams et al., 1989). Variations on STSL have been reported by Testut (1904) and Poirier \& Charpy (1911). Calcification, partial or complete ossification and multiple bands were also discussed by Ticker et al., (1998) and related by others authors (Osuagwu et al., 2005; Khan). Moreover, others studies have been observed the prevalence of these variations (Kajava, 1924; Vallois,1925; Vallois, 1926; Gray, 1942; Lewis, 1959).

The suprascapular artery and vein pass over the superior aspect of the STSL (Antoniadis et al., 1996; Weinfeld et al., 2002). The suprascapular notch and the overlying STSL constitute a narrow foramen, with inflexible and often sharp edges, through which the suprascapular nerve must pass (Williams et al.; Weinfeld et al.). The suprascapular nerve is fixed in the osteofibrous foramen of the notch and STSL and by its distal muscular and joint connections (Gelmers \& Byus, 1977; Antoniadis et al.; Weinfeld et al.). Mechanical irritation of the suprascapular nerve can occur at this location with excursions of the scapula, particularly during crossbody abduction, during a variety of activities involving movement of the upper extremity (Clein, 1975; Gelmers \& Buys; Antoniadis et al.; Weinfeld et al.).

The ossification of the STSL was considered anomalous by Lewis and Harris et al., (2001), suggesting

* Department of Anatomy, Biomedical Science Center, Gama Filho University, Brazil.

** Department of Anatomy, Biomedical Institute, Federal Rural University of Rio de Janeiro, Brazil.

**** Department of Morphology, Biomedical Institute, Fluminense Federal University (Rio de Janeiro), Brazil.

*****Department of Anatomy, Health Science Center, Vale do Itajaí University, (Santa Catarina), Brazil. 
SILVA, J. G.; ABIDU-FIGUEIREDO, M.; FERNANDES, R. M. P.; AURELIANO-RAFAEL, F.; SGROTT, E. A.; SILVA, S. F. \& BABINSKI, M. A. High incidence of complete ossification of the superior transverse scapular ligament in Brazilians and its clinical implications. Int. J. Morphol., 25(4):855-859, 2007.

one more factor to calcification of STSL and suprascapular nerve entrapment syndrome.

In the diagnosis of suprascapular nerve entrapment syndrome, anatomical variations of the STSL sometimes feature in the hierarchy of possible etiologic factors (Callahan et al., 1991). However, this syndrome has also ossification of the STSL (Osuagwu et al.). Complete ossification of the STSL or suprascapular nerve entrapment syndrome has not been previously described amongst Brazilians. Therefore, the proposal of this study was to verify the prevalence of the STSL ossified in Brazilians dry bones.

\section{MATERIAL AND METHOD}

This work was performed according to the provisions of the declaration of Helsinki in 1995 (as revised in Edinburgh, 2000). Guidelines for our internal review board were found in the observations made and the protocol was approved by local Department of Morphology.

Two hundred twenty one scapulae (dry bones) were analyzed: 111 rights and 110 lefts, proceeding of the collection of three universities from Rio de Janeiro state and one university of Santa Catarina state. As exclusion criterion, were not analyzed bones of children or damaged.

The exam was performed by presence of STSL completely ossified. It was adopted like exclusion criterion all the children scapulae and the scapulae which the superior margin of bone were bilaterally damaged. All the analyzed parameters were independent of sex or race.

For the quantitative analysis of the data, the software Graphad Instat (Graphpad) was used. The tests of Kolmogorov-Smirnov were used to analyze if the data were within the normal distribution. Fisher exact test was used to verify the relation between showed in Table I. The $\mathrm{p} \leq$ 0,05 was considered significant. been described in clinical scenarios without a visible

\section{RESULTS}

Macroscopic examination revealed that $68 / 221$ $(30,76 \%)$ of analyzed scapulae presented the ossified STSL creating a forame (Figs.1 and 2). The data obtained are considered statically significant $(\mathrm{p} \leq 0,0001)$ (Table I and Fig.3). In this group, it was observed that 36/68 (52,94\%) were ossified on the right side and $32 / 68(47,05 \%)$ on the left one. In the 153 scapulae that did not present the ossified STSL, 30/153 (19,6\%) have been showed the superior edge varying at transverse plan, creating a superior angulations; which, in the specimens studied, modified the form at depth and width of the scapular notch.

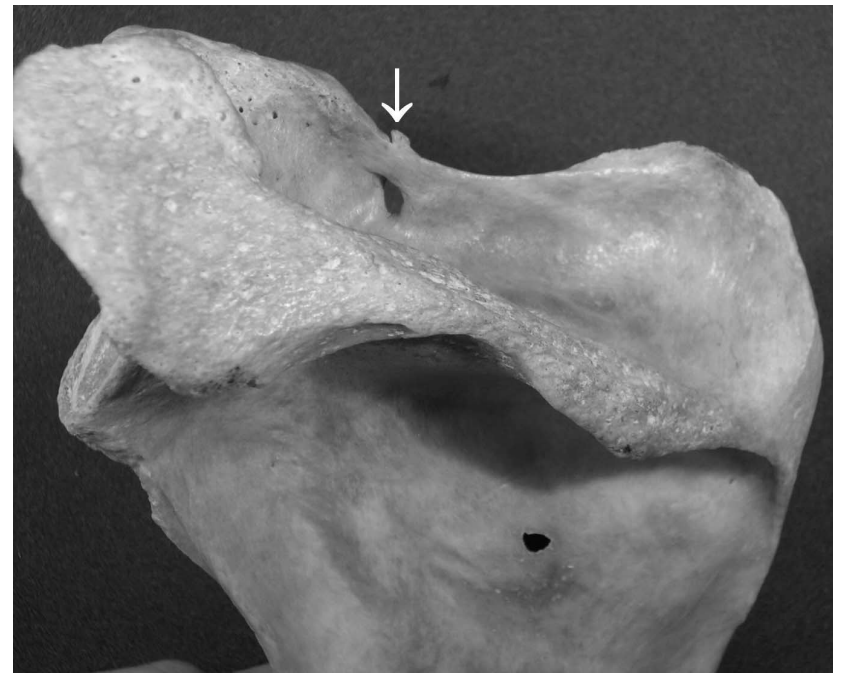

Fig. 1. Posterior-superior view of the left scapula showing ossified STSL (arrow).

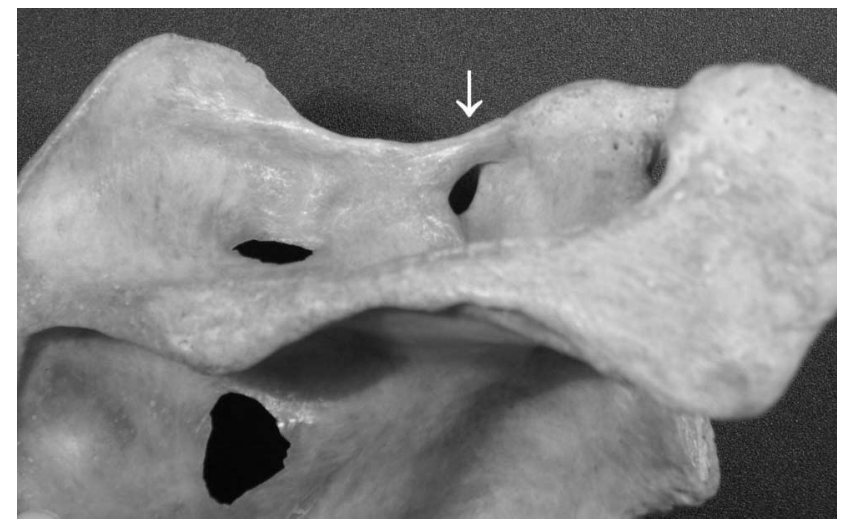

Table I. Analysis between percent data waited (*) vs obtained of the 221 scapulae studied.

\begin{tabular}{lcc}
\hline Anatomic elements & Waited data & Obtained data \\
Suprascapular notch - normal anatomy of dry bone & $90 \%$ & $?$ \\
Ossified STSL - abnormal anatomy of dry bone & $10 \% *$ & $?$ \\
Total & $100 \%$ & $100 \%$ \\
\hline
\end{tabular}

Fig. 2. Posterior-superior view of the left scapula showing ossified STSL (arrow)

*Estimated data above of that it was found in literature (Poirier \& Charpy, 1911; Kajava,1924;

Vallois,1925,1926; Gray,1942). 


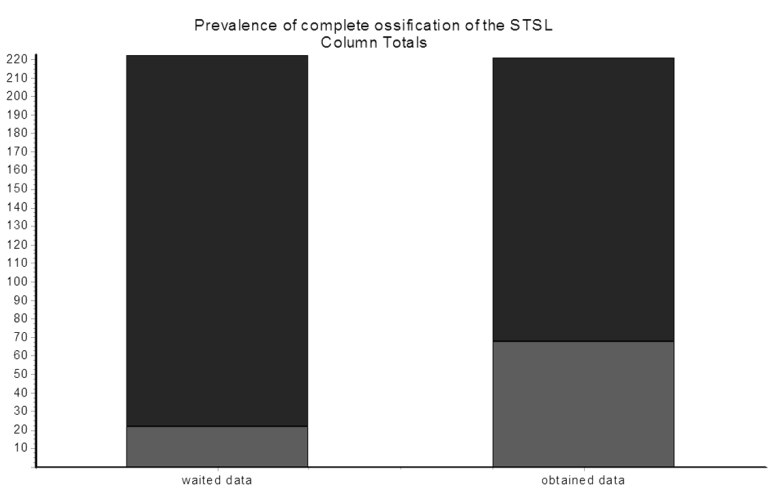

Fig. 3. Representative graphic of the results between waited data comparing with obtained data. 221 specimens analyzed: black color= suprascapular notch (normal anatomy); gray color $=$ ossified STSL (abnormal anatomy).

\section{DISCUSSION}

The complete ossification of the STSL converting the suprascapular notch into foramen was found in three of $60(5 \%)$ scapulae by Poirier \& Charpy. In 133 finish scapulae studied by Kajava, the foramen was present only twice $(1.5 \%)$. Vallois (1925) found the foramina to occur 13 times in $200(6.5 \%)$ scapulae of French men. In a second study Vallois, (1926) reported that Italian scapulae had foramina in $6.1 \%$ and in a series of scapulae from various sources, the incidence varied from $0 \%$ to $3.3 \%$. Gray found foramen in 73 of 1.151 scapulae $(6.34 \%)$, but no suprascapular foramina were found in 87 Indian scapulae.

To our knowledge, this work is the first to quantify the variation of STSL ossified in Brazilians. We could observed in the subjects a significant percentage of $30.76 \%$ $(68 / 221)$ considered statically significant $(p \leq 0,0001)$. Comparing with other studies, we verify a high percentage of frequency at Brazilians (Poirier \& Charpy; Kajava; Vallois, 1925; Vallois, 1926; Gray). About the alteration of the superior edge scapular, we can relate this to shortening or adaptation for muscular overuse that fix at superior edge, during the life. The muscles, supraspinatus and scapula elevator transit in this region can be related to the STSL calcification, associated to the muscular groupings of this region. Certain habits of life at utilization of the upper limb can also intervene at the process.

Some studies try to elucidate the alterations provoked in the structures of the human skeleton, in special at sports (Ringel et al.; Tengan et al.; Wang \& Koehler). Sandow \& Ilic have been discussed about the specific volleyball movements and their implications at suprascapular nerve compression. The characteristically gestures e.g. of volleyball players as abduction associate lateral (external) rotation are factors that predispose the neuropraxis. These data justify our results and the anatomical exploration of the scapular notch region and the STSL.

The most recent papers do not elucidate reasons for the STSL ossification, they only analyze that this condition promotes the suprascapular nerve syndrome (Prescher). The ossified STSL can be a risky factor at surgical explorations during a suprascapular nerve decompression (Ticker et al.).

Cohen et al. have been described a familial case of calcification of STSL affecting a 58 year old man and his son, who had STSL calcification causing entrapment neuropathy of the suprascapular nerve, clinical symptoms of pain, weakness of the external rotation and abduction, and atrophy of the supraspinatus muscle (Weinfeld et al.). There are reports in the literature about bifid (Alon et al., 1998) and trifid (Ticker et al.) STSL, with the former including an account of ensuing suprascapular nerve entrapment.

Rengachary et al. have been observed six different types of anatomical variations in the suprascapular notch area. These variations of the suprascapular notch and the STSL constitute potential predisposing factors to suprascapular nerve entrapment. However, Harris et al., promoted new discusses about the suprascapular notch area. They showed that conoid ligament has accessory fascicle, the lateral border of the scapular notch at the junction of the conoid and STLS. This variation is considered anomalous by Harris et al., but it is mentioned by Testut and Lewis, suggesting one more factor to calcification of STSL and suprascapular nerve entrapment.

Despite this possible relationship between suprascapular nerve entrapment syndrome and the morphological differences, in the infraspinatus or supraspinatus muscle and variations in the STLS, we were unable to correlate all the aforementioned in the subject of this case report due the poor documentation (Osuagwu et al.; Khan). The present study demonstrates that complete ossification of STSL is common and can occur usually in Brazilians.

The anatomical knowledge of the STSL ossified are of extreme importance for the clinicians that approaches painful syndrome of the shoulder, as well as, this anatomical curiosity should be kept in mind by students and surgeons that may manipulate this anatomical area. 
SILVA, J. G.; ABIDU-FIGUEIREDO, M.; FERNANDES, R. M. P.; AURELIANO-RAFAEL, F.; SGROTT, E. A.; SILVA, S. F. \& BABINSKI, M. A. High incidence of complete ossification of the superior transverse scapular ligament in Brazilians and its clinical implications. Int. J. Morphol., 25(4):855-859, 2007.

SILVA, J. G.; ABIDU-FIGUEIREDO, M.; FERNANDES, R. M. P.; AURELIANO-RAFAEL, F.; SGROTT, E. A.; SILVA, S. F. \& BABINSKI, M. A. Alta incidencia de osificación completa del ligamento escapular transverso superior en brasileños y sus implicancias clínicas. Int. J. Morphol., 25(4):855-859, 2007.

RESUMEN: El objetivo de este estudio fue verificar la prevalencia del ligamento escapular transverso superior (LETS) osificado, en huesos secos. 221 escápulas secas (111 derechas y 110 izquierdas) fueron analizadas,procedentes de Río de Janeiro y de Santa Catarina, Brasil. No fueron analizados huesos de niños o dañados. El tratamiento estadístico de los datos fue realizado con el software Graphpad Instat, siendo seleccionado el test Fisher, con un $\mathrm{p} \leq 0.05$ como significativo. El 30.76\% (68/221) de las escápulas presentaron el LETS osificado ( $\leq \leq 0,0001)$ de ellos, el 52.94\% (36/68) correspondían a escáulas derechas y 47.05\% (32/68) a escápulas izquierdas. Las 153 escápulas que no presentaron el LETS osificado, se observó en el 19.6\% (30/153) de estos huesos. El margen superior que variaba en el plano transversal, incrementaba la angulación superior y modificaba así el ancho y la profundidad de la incisura escapular. Esta variación anatómica la deben tener presente los clínicos debido al síndrome doloroso del hombro, como también, los estudiantes que manipulan esta área anatómica.

PALABRAS CLAVE: Anatomía; Variation; Escápula; Ligamento escapular transverso superior.

\section{REFERENCES}

Alon, M.; Weiss, S.; Fischel, B. \& Dekel, S. Bilateral suprascapular nerve entrapment syndrome due to anomalous transverse scapular ligament. Clin. Orthop., 234:31-3, 1988.

Antoniadis, G.; Richter, H.P.; Rath, S.; Braun, V. \& Moese, G. Suprascapular nerve entrapment: Experience with 28 cases. J. Neurosurg., 85:1020-5, 1996.

Bergman, R. A.; Thompson, S. A.; Afifi, A. K. \& Saadeh, F. A. Compendium of Human Anatomic Variation. Baltimore, Urban \& Schwarzenberg, 1988.

Callahan, J. D.; Scully, T. B.; Shapiro, S. A. \& Worth, R.M. Suprascapular nerve entrapment. A series of 27 cases. $J$. Neurosurg., 74:893-6, 1991.

Clein, L. J. Suprascapular entrapment neuropathy. J. Neurosurg., 43:337-42, 1975.

Cohen, S. B.; Dnes, D. M. \& Moorman, C. T. Familial calcification of the superior transverse scapular ligament causing neuropathy. Clin. Orthop. Rel. Res., 334:131-5, 1997.

Gardner, E.; Gray, D. J. \& O’Hailly, R. Anatomia: estudo regional do corpo humano. $4^{\mathrm{a}}$. ed. Rio de Janeiro, Guanabara Koogan, 1988.

Gelmers, H.J. \& Buys, D.A. Suprascapular entrapment neuropathy. Acta Neurochir., 38:121-4, 1977.

Gray, D. J. Variations in the human scapulae. Am. J. Phys. Anthropol., 29:57-72, 1942.
Harris, R. I.; Vu, D. H.; Sonnabend, D. H.; Goldberg, J. A. \& Walsh, W.R. Anatomic variance of the coracoclavicular ligaments. J. Shoulder Elbow Surg., 10:585-8, 2001.

Kajava, Y. Uber den Schultergiirtel der Finen. Ann. Acad. Sci. Fenn, Series A., 21(5):1-69, 1924.

Khan, M.A. Complete ossification of the superior transverse scapular ligament in an indian male adult. Int. J. Morphol., 24(2):195-6, 2006.

Lewis, O. J. The coracoclavicular joint. J. Anat., 93: 296$303,1959$.

Osuagwu, F. C.; Imosemi, I.O. \& Shokunbi, M.T. Complete ossification of the superior transverse scapular ligament in a Nigerian male adult. Int. J. Morphol., 23(2):121-2, 2005.

Poirier, P. \& Charpy, A. Traite d'Anatomia Humaine. $3^{\text {th }}$ ed. Paris, 1911.

Prescher, A. Anatomical basics, variations, and degenerative changes of the shoulder joint and shoulder girdle. Eur. J. Radiol., 35(2):88-102, 2000.

Rengachary, S. S.; Burr, D.; Lucas, S.; Hassanein, K.M.; Mohn, M.P. \& Matzke, H. Suprascapular entrapment neuropathy: a clinical, anatomical, and comparative study. Part 2. Anatomical study. Neurosurg., 5:447-51, 1979.

Ringel, S. P.; Treihaft, M.; Carry, M.; Fisher, R. \& Jacobs, 
SILVA, J. G.; ABIDU-FIGUEIREDO, M.; FERNANDES, R. M. P.; AURELIANO-RAFAEL, F.; SGROTT, E. A.; SILVA, S. F. \& BABINSKI, M. A. High incidence of complete ossification of the superior transverse scapular ligament in Brazilians and its clinical implications. Int. J. Morphol., 25(4):855-859, 2007.

P. Suprascapular neuropathy in pitchers. Am. J Sport Med., 18:80-6, 1990.

Sandow, M.J. \& Ilic, J. Suprascapular nerve rotator cuff compression syndrome in volleyball players. $J$. Shoulder Elbow Surg.,7(5):516-21, 1998.

Tengan, C. H.; Oliveira, A. S. B.; Kimoto, B. H.; Morita, M. P. A.; Medeiros, J. L. A. \& Gabbai, A. A. lsolated and painless infraspinatus atrophy in top-level volleyball players: report of two cases and review of the literature. Arq. Neuropsiquiatr., 5(1):125-9, 1993.

Testut, L. Traite d'anatomie humaine. Octave Dion, Paris, 1904. V. 1.

Ticker, J. B.; Djurasovic, M.; Strauch, R. J.; April, E.W.; Pollock, R. G.; Flatow, E. L. \& Bigliani, L.U. The incidence of ganglion cysts and variations in anatomy along the course of the suprascapular nerve. J. Shoulder Elbow Surg., 7(5):472-8, 1998.

Vallois, H. V. L'os acromial dans les races humaine. L' Anthropologie, Paris, 35:977-1022, 1925.

Vallois, H. V. Variations de la cavite glenoide de l'omoplate. Soc. Biol. Comptes Rendus Hebdomadaires. Soc. Seances et inenoriores., 94:559-60, 1926.

Wang, D. H. \& Koehler, S. M. Isolated infraspinatus atrophy in a collegiate volleyball player. Clin. J. Sport Med., 6:255-8, 1996.

Weinfeld,A. B.; Cheng, J.; Nath, R. K.; Basaran, I.; Yuksel, E. \& Rose, J. E. Topographic mapping of the superior transverse scapular ligament: a cadaver study to facilitate suprascapular nerve decompression. Plast. Reconstr. Surg., 110:774-9, 2002.

Williams, P.L.; Warwick, R.; Dyson, M. \& Bannister, L. H. Gray's Anatomy. Churchill Livingstone, New York, 1989.
Correspondence to:

Prof. Dr. Marcio Antonio Babinski

Department of Morphology

Biomedical Center

Fluminense Federal University

Av. Hernani Mello 101

CEP 24.210-150

Niterói, Rio de Janeiro

BRAZIL

Phone: + 5521 2587-6499

Fax: + 5521 2587-6121

E-mail: mababinski@gmail.com mababinski@vm.uff.br

Received: 22-07-2007

Accepted: 22-10-2007 
